Tropical Journal of Pharmaceutical Research February 2017; 16 (2): 363-369

ISSN: $1596-5996$ (print); 1596-9827 (electronic)

(C) Pharmacotherapy Group, Faculty of Pharmacy, University of Benin, Benin City, 300001 Nigeria.

All rights reserved.

Available online at http://www.tjpr.org

Original Research Article

http://dx.doi.org/10.4314/tjpr.v16i2.15

\title{
Anti-nociceptive effect of total alkaloids isolated from the seeds of Areca catechu L (Arecaceae) in mice
}

\author{
Lei Zhao ${ }^{1 *}$, Yu Li ${ }^{1}$, Shaohui Yang ${ }^{2}$, Pei Zhang ${ }^{1}$ and Jing Wang ${ }^{1}$ \\ ${ }^{1}$ Department of Pain, ${ }^{2}$ Department of Cardiology, The First Affiliated Hospital and College of Clinical Medicine of Henan \\ University of Science and Technology, Luoyang 471003, PR China
}

*For correspondence: Email: hnunist@126.com; Tel: +86-0379-64897112

\begin{abstract}
Purpose: To investigate the antinociceptive effect of the total alkaloids (TA) isolated from the seeds of Areca catechu $L$. (SAC) and to elucidate the probable mechanism of action.

Methods: TA extraction conditions including concentration of ethanol, extraction temperature, liquidsolid ratio and designed $\mathrm{pH}$ were optimized by an orthogonal experiment $\left\{\mathrm{L} g_{(}(3)^{4}\right\}$ test. The antinociceptive effect of the extract in mice was evaluated by acetic acid writhing reflex test, hot plate test, capsaicin-induced nociception test, tail-flick test and formalin-induced pain test in mice. Furthermore, pretreatment of the animals with naloxone $(2 \mathrm{mg} / \mathrm{kg}$ ) was performed to investigate whether the antinociceptive effect involved the opioid route or not. The locomotor activity of TA in mice were also assessed.

Results: The optimum extraction conditions of TA were as follows: solid-liquid ratio of 1: $15(\mathrm{~W} / \mathrm{V})$, ethanol concentration of $80 \%, \mathrm{pH}$ of 9.0 and extraction temperature of $70^{\circ} \mathrm{C}$. Oral administration of TA produced a marked anti-nociceptive activity in mice, and pretreatment with naloxone did not reverse the anti-nociceptive activity of TA in mice. Also, the locomotor activity of mice was not affected by TA. In addition, TA significantly down-regulated the expression levels of COX-2 in the dorsal root of mice spinal cord at 100, 200 and $400 \mathrm{mg} / \mathrm{kg}$ doses.

Conclusion: The results demonstrate that TA possesses significant anti-nociceptive effects, and the mechanisms are closely related to suppression of COX-2 expression. Overall, the results provided scientific support for the use of TA in treatment of pain.
\end{abstract}

Keywords: Areca catechu, Total alkaloids, Anti-nociceptive, Formalin-induced pain, Naloxone

Tropical Journal of Pharmaceutical Research is indexed by Science Citation Index (SciSearch), Scopus, International Pharmaceutical Abstract, Chemical Abstracts, Embase, Index Copernicus, EBSCO, African Index Medicus, JournalSeek, Journal Citation Reports/Science Edition, Directory of Open Access Journals (DOAJ), African Journal Online, Bioline International, Open-J-Gate and Pharmacy Abstracts

\section{INTRODUCTION}

Although pain can be considered as protective mechanism of the body, it disrupts the life quality of millions of people all over the world, and brings a heavy burden to both individuals and society $[1,2]$. Classical types of analgesic medication for treating pain include non-steroidal anti-inflammatory drugs (NSAIDs) and opioids [3]. However, long-term use of NSAIDs can induce some adverse effects, such as gastric mucosal injury and hemorrhage, and the repeated use of opioids can induce severe drug dependence $[4,5]$. Thus, the clinical efficacy and application of conventional analgesics were limited by their unwanted adverse effects.

The use of natural products are increasing in treating pain as alternative therapies to the conventional medical approaches [6]. Areca catechu L., belonging to Arecaceae family, is widely distributed in South-Asian countries. It is a folk medicine employed to treat some diseases, such as gastrointestinal inflammation, dysentery 
and diarrhea [7]. The seeds of Areca catechu L. (SAC), is one of Traditional Chinese Medicines used for the treatment of distended abdomen and intestinal parasitosis, tenesmus and diarrhea [8]. Alkaloids were the major active constituents of SAC which had many pharmacological activities [9]. Although, anti-nociceptive effects of this drug have been reported [10], limited evidence is available to confirm its effective constituents. The present study was designed to explore the anti-nociceptive effects of total alkaloids isolated from areca nut, which was conducive to the development of this drug.

\section{EXPERIMENTAL}

\section{Chemicals and reagents}

Acetic acid, capsaicin, naloxone hydrochloride, indomethacin, diazepam solution $(1 \mathrm{mg} / \mathrm{mL})$ and morphine solution $(1 \mathrm{mg} / \mathrm{mL})$ were purchased from Sigma Aldrich (St. Louis, MO, USA). Anticyclooxygenase-2 (COX-2) rabbit monoclonal IgG and goat anti-rabbit/HRP conjugate were purchased from Cayman Chemical Company (Ann Arbor, Michigan). Other chemicals used were of analytical grade.

\section{Preparation of total alkaloids from SAC}

SAC materials were purchased from Yuzhou Chinese Herbal Medicine Professional Market (Yuzhou, China). They were authenticated by the Department of Traditional Chinese Medicine in He'nan University of Science and Technology Luoyang, China. A voucher specimen was deposited in the herbarium of the First Affiliated Hospital of He'nan University of Science and Technology (No. YPLY-2016-07-21). The extraction methods were performed as previously reported [11] with some modifications. The powder $(5.0 \mathrm{~g})$ of SAC was weighed and placed in a $100 \mathrm{~mL}$ triangular flask containing ethanol. Then an ultrasound extraction was carried out with different ethanol concentration (70, 80 and $90 \%)$, extraction temperature $(50,60$ and 70 $\left.{ }^{\circ} \mathrm{C}\right)$, and liquid-solid ratio (1: 10, 1: 15 and 1: 20, $\mathrm{w} / \mathrm{v}$ ) for $30 \mathrm{~min}$. The extraction solutions were collected and concentrated, and adjusted to designed $\mathrm{pH}(7.0,8.0$ and 9.0$)$ by ammonium hydroxide. After that, the solutions were extracted by trichloromethane for three times and finally freeze drying to obtain TA. The extraction yield of TA $(\mathrm{mg} / \mathrm{g})$ was calculated by equation (1):

$\mathrm{Y}(\mathrm{mg} / \mathrm{g})=\mathrm{W}_{1} \mathrm{~W}_{0}$

where $Y$ was the yield of extracted alkaloids, $W_{1}$ was the weight of extracted alkaloids $(\mathrm{mg})$, and $\mathrm{W}_{0}$ was weight of dried powder sample $(\mathrm{g})$.

\section{Optimization of TA extraction}

An orthogonal experiment $\left\{L_{9}(3)^{4}\right\}$ test design was employed in the present study for optimizing the extraction conditions of TA. The key parameters that influenced the yield of TA including liquid-solid ratio, concentration of ethanol, extraction temperature, and the $\mathrm{pH}$ value were analyzed. The experimental design for the extraction of TA from SAC were shown in Table 1.

\section{Determination of alkaloid content in TA}

The content of alkaloid in TA was determined by acid dye colorimetry method [12]. Briefly, the samples were dissolved by acetic acid-sodium acetate buffer solution $(\mathrm{pH}=5)$. Then the bromocresol green solution $(0.8 \mathrm{mg} / \mathrm{mL})$ was added to the samples and extracted by trichloromethane for three times. The trichloromethane solution was collected, and anhydrous ethanol solution of potassium hydroxide $(0.01 \mathrm{~mol} / \mathrm{L})$ was added before detecting the absorbance at $618 \mathrm{~nm}$. Arecoline hydrobromide was used as standard substance.

\section{Animals}

Female KM mice (18 - $22 \mathrm{~g}$ ) were obtained from Laboratory Animal Center of He'nan University of Science and Technology (Luoyang, China). Animals were housed in controlled environment (temperature of $23 \pm 1{ }^{\circ} \mathrm{C}$ under a 12-h light-dark cycle, $50-60 \%$ humidity) for 7 days before the experiment. Feed and water were provided ad libitum. The experiments were approved by the Institutional Ethics Committee for Animal Care and Use of the First Affiliated Hospital of He'nan University of Science and Technology (approval no. SYDW 201602-08),

Table 1: Orthogonal experiment design (four factors and three levels)

\begin{tabular}{|c|c|c|c|c|}
\hline Factor & $\begin{array}{c}\mathrm{A} \\
\text { Solid-liquid ratio }(w / v)\end{array}$ & $\begin{array}{c}\mathrm{B} \\
\text { Ethanol concentration (\%) }\end{array}$ & $\begin{array}{c}\mathrm{C} \\
\mathrm{pH}\end{array}$ & $\begin{array}{c}\mathrm{D} \\
\text { Temperature }\left({ }^{\circ} \mathrm{C}\right)\end{array}$ \\
\hline 1 & $1: 10$ & 70 & 7.0 & 50 \\
\hline 2 & $1: 15$ & 80 & 8.0 & 60 \\
\hline 3 & $1: 20$ & 90 & 9.0 & 70 \\
\hline
\end{tabular}


and conducted in accordance with Principles of Laboratory Animal Care (NIH publication no. 8523, revised 1985) [13].

\section{Acetic acid-induced abdominal writhing test}

Acetic acid-induced abdominal writhing was performed as previously reported by Wang et al [14]. Mice were randomly divided into five groups $(n=10)$ : the control group [normal saline (NS)], three TA groups $(100,200$ and $400 \mathrm{mg} / \mathrm{kg}$ ), and the indomethacin group $(10 \mathrm{mg} / \mathrm{kg})$. TA, NS and indomethacin were all administered orally (i.g.) to animals $(10 \mathrm{~mL} / \mathrm{kg}) 1 \mathrm{~h}$ before acetic acid solution $(0.7 \% \quad \mathrm{v} / \mathrm{v}, 10 \mathrm{~mL} / \mathrm{kg})$ injected intraperitoneally (i.p.). The number of writhing of each mouse was counted after acetic acid injection over a period of $12 \mathrm{~min}$.

\section{Hot plate test}

Hot plate test was carried out using the methods as previously described by Suseem et al [15]. The metal surface was maintained at the temperature of $50 \pm 1{ }^{\circ} \mathrm{C}$. Latency time was defined as the duration until the mouse jumped off the plate or licked its hind paw to avoid thermal stimulation. All mice were screened before the test, and a pre-test latency (5-30 s) qualified them for the experiment. The mice were treated with TA (100, 200 and $400 \mathrm{mg} / \mathrm{kg}$, i.g.) or NS $(10 \mathrm{~mL} / \mathrm{kg}$, i.g.) one hour before the test. Morphine $(10 \mathrm{mg} / \mathrm{kg}$, i.p.) was administered 30 min before the test. Additionally, to avoid tissue damage of the mouse, a cut off time (60 s) was used.

\section{Capsaicin-induced nociception test}

The procedure used in the present study was same to that previously described by Pinheiro et al [16]. Capsaicin (1.6 $\mu \mathrm{g} /$ paw, $20 \mu \mathrm{L}$ ) was injected subcutaneously (s.c.) in the mice right hind paw. Animals were treated with TA (100, 200 and $400 \mathrm{mg} / \mathrm{kg}$, i.g.) one hour before capsaicin injection. The mice in the control group received NS (10 mL/kg, i.g.), while the mice in positive control group received morphine (10 $\mathrm{mg} / \mathrm{kg}$, i.p.). Each mouse was observed individually for $5 \mathrm{~min}$ following capsaicin injection, and the time of the animal spent for licking the injected paw was recorded.

\section{Tail-flick test}

Antinociceptive activity of TA was further assessed using the tail-flick test [17]. Mice were treated with TA $(100,200$ and $400 \mathrm{mg} / \mathrm{kg}$, i.g.) or NS $(10 \mathrm{~mL} / \mathrm{kg}$, i.g.) one hour before the test. Morphine (10 mg/kg, i.p.) was administered to mice in the positive group $30 \mathrm{~min}$ before the experiment. The tail of each mouse was immersed in a hot water bath (maintained at $55 \pm$ $1^{\circ} \mathrm{C}$ ). Each mouse was recorded the reaction time to flick the tail from the hot water. A cut off time of $7 \mathrm{~s}$ was used to prevent any injury to the tail of the mouse.

\section{Formalin-induced pain test}

The formalin-induced pain test was performed per the study of Wandji et al [18]. Mice were treated with TA (100, 200 and $400 \mathrm{mg} / \mathrm{kg}$, i.g.) or NS (10 ml/kg, i.g.) one hour before the test. Morphine (10 mg/kg, i.p.) was administered to mice in the positive group $30 \mathrm{~min}$ before the test. Animals were injected with $5 \%$ formalin $(20 \mu \mathrm{L}$, s.c.) into the dorsal hind paw and observed in individual cages post formalin injection. Two distinct phases were observed: phase I, 0-5 min; phase II, 15-25 min. The time of the mice spent biting or licking the injected paw or leg was recorded. Furthermore, the mechanism of action of TA was evaluated by testing their analgesic effects in animals pre-treated with naloxone (1 $\mathrm{mg} / \mathrm{kg}$, i.p.) $15 \mathrm{~min}$ before the formalin test.

\section{Evaluation of effect of TA on COX-2 in formalin induced pain}

After formalin test, the mice were deeply anesthetized with sodium pentobarbital (50 $\mathrm{mg} / \mathrm{kg}$, i.p.). Thereafter, the spinal cord was quickly removed, an intact L4 L6 dorsal root was cut and stored into $-80{ }^{\circ} \mathrm{C}$ liquid nitrogen pending further experiments [19]. To evaluate the COX-2 expression in the dorsal horn of the spinal cord, total proteins of spinal cord tissue were extracted. Equal amounts of protein $(50 \mu \mathrm{g})$ were separated by sodium dodecyl sulfate/ polyacrylamide gel electrophoresis (SDS/PAGE) and then transferred onto a polyvinylidene difluoride (PVDF) membrane. The membrane was then incubated with an anti-COX-2 rabbit monoclonal IgG followed by a goat antirabbit/HRP conjugate. The proteins were detected by using chemiluminescence reagents. Antibodies directed against $\beta$-actin were used to normalize for protein loading.

\section{Determination of locomotor activity}

The effect of the TA on spontaneous locomotor activity was assessed using the open-field test. Mice were treated with TA $(100,200$ or 400 $\mathrm{mg} / \mathrm{kg}$, i.g.) or the NS (10 mL/kg,) or diazepam (2 $\mathrm{mg} / \mathrm{kg}$, i.p.) one hour before the test. The number of locomotor activity of each mouse was recorded within $5 \mathrm{~min}$ period using a multi- 
functional mice locomotor activity recorder (Yiyan technology development co., LTD, Jinan, China).

\section{Statistical analysis}

Statistical analysis was performed by SPSS version 16.0 (SPSS Inc., USA). All data are expressed as mean $\pm S E M$, and were analysed by one-way ANOVA followed by Dunnett's multiple comparison. $P<0.05$ was considered statistically significant.

\section{RESULTS}

\section{Optimization by orthogonal experimental design}

An extreme different analysis shows that the effect of the four factors on the extraction yield of TA is solid-liquid ratio > extraction temperature $>$ $\mathrm{pH}>$ ethanol concentration (Table 2). According to the variance analysis in Table 3 , the contributions of solid-liquid ratio $(p<0.01)$ and $\mathrm{pH}(p<0.05)$ for the extraction yield of TA are significant, whereas ethanol concentration and extraction temperature are not significant factors. According to extreme difference analysis, the optimum extraction conditions of TA were: solidliquid ratio of $1: 15(\mathrm{w} / \mathrm{v})$, ethanol concentration of $80 \%, \mathrm{pH}$ value of 9.0 , and extraction temperature of $70^{\circ} \mathrm{C}$.

Table 2: Orthogonal design test results

\begin{tabular}{lccccc}
\hline $\begin{array}{l}\text { Test } \\
\text { no. }\end{array}$ & A & B & C & D & $\begin{array}{c}\text { Yield } \\
(\mathbf{m g} / \mathbf{g})\end{array}$ \\
\hline 1 & 1 & 1 & 1 & 1 & 1.72 \\
2 & 1 & 2 & 2 & 2 & 1.82 \\
3 & 1 & 3 & 3 & 3 & 1.89 \\
4 & 2 & 1 & 2 & 3 & 2.22 \\
5 & 2 & 2 & 3 & 1 & 2.37 \\
6 & 2 & 3 & 1 & 2 & 2.19 \\
7 & 3 & 1 & 3 & 2 & 1.75 \\
8 & 3 & 2 & 1 & 3 & 1.71 \\
9 & 3 & 3 & 2 & 1 & 1.66 \\
K1 & 1.810 & 1.897 & 1.873 & 1.917 & \\
K2 & 2.260 & 1.967 & 1.900 & 1.920 & \\
K3 & 1.707 & 1.913 & 2.003 & 1.940 & \\
Extreme & 0.553 & 0.070 & 0.130 & 0.023 & \\
value & & & & & \\
\hline & & & & &
\end{tabular}

Table 3: Variance analysis (orthogonal test)

\begin{tabular}{lcccc}
\hline Source & SS & df & F-value & Significance \\
\hline A & 0.519 & 2 & 519.000 & $p<0.01$ \\
B & 0.008 & 2 & 8.000 & $p>0.05$ \\
C & 0.028 & 2 & 28.000 & $p<0.05$ \\
D & 0.001 & 2 & 1.000 & $p>0.05$ \\
\hline
\end{tabular}

To confirm the predicted optimum condition of TA, extractions under predicted optimum conditions were carried out, and the extraction yield of TA was $2.41 \pm 0.12 \mathrm{mg} / \mathrm{g}$. Therefore, it's confirmed that the predicted conditions were the best combination of different parameters. In addition, the results of content determination showed that the average content of alkaloid in the TA was $70.75 \%$, indicating that alkaloids were the main constituents of TA.

\section{Anti-nociceptive effect of TA}

\section{Acetic acid writhing reflex}

The effect of TA on the writhing response in mice was shown in Figure 1. The indomethacin (10 $\mathrm{mg} / \mathrm{kg}$ ) significantly inhibited acetic acid induced writhing response compared with mice in the control group $(p<0.01)$. Interestingly, TA also significantly inhibited the acetic acid induced writhing response in mice compared with the control group. The inhibitory effect was in a dose dependent manner at the doses of 100, 200 and $400 \mathrm{mg} / \mathrm{kg}(p<0.05, p<0.01$ and $p<0.01$, respectively).

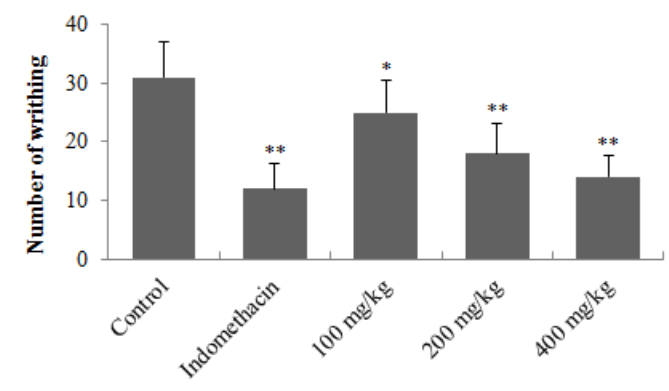

Figure 1: Effect of TA on acetic acid-induced writhing reflex in mice. ${ }^{*} p<0.05$, compared with control group; ${ }^{* *} p<0.01$, compared with control group

\section{Latency time}

In the hot plate test, morphine $(10 \mathrm{mg} / \mathrm{kg})$ displayed marked anti-nociceptive effects in mice $(p<0.001)$, compared with the control group. As shown in Figure 2, TA also significantly increased the latency time at the doses of 200 and $400 \mathrm{mg} / \mathrm{kg}(p<0.01)$ as compared with the control group.

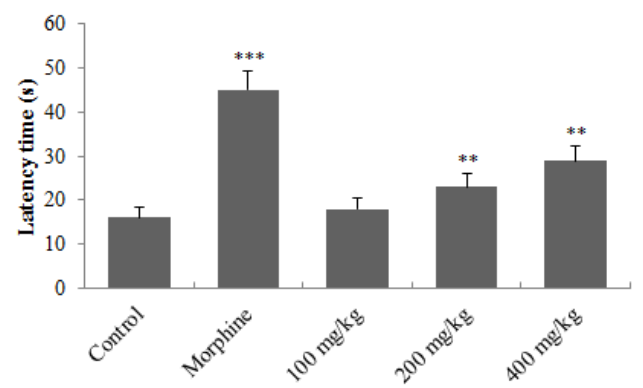

Figure 2: Effect of TA on the latency time in hot plate test. ${ }^{* \star} p<0.01$, compared with control group; ${ }^{* \star *} p<$ 0.001 , compared with control group 


\section{Capsaicin-induced nociception}

The effects of TA on capsaicin-induced nociception in mice were shown in Figure 3. From the results, TA showed significant inhibitory effect on capsaicin-induced neurogenic nociception dose-dependently at 100, 200 and $400 \mathrm{mg} / \mathrm{kg}(p<0.05, p<0.01$ and $p<0.001)$, compared with the control group. Morphine (10 $\mathrm{mg} / \mathrm{kg}$ ) also significantly inhibited the capsaicininduced neurogenic nociception compared with the control group.

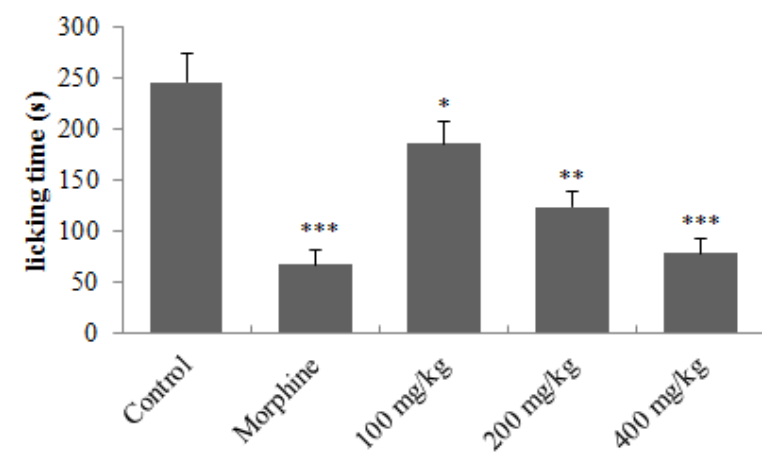

Figure 3: Effect of TA on Liking time in capsaicininduced nociception. ${ }^{*} p<0.05$, compared with control group; ${ }^{* *} p<0.01$, compared with control group; ${ }^{* * *} p<$ 0.001 , compared with control group

\section{Tail-flick reaction time}

TA significantly increased the reaction time on mice in tail-flick test at the doses of 200 and 400 $\mathrm{mg} / \mathrm{kg}(p<0.01$ and $p<0.001)$, compared with mice in the control group (Figure 4). In addition, morphine $(10 \mathrm{mg} / \mathrm{kg})$ also produced significant analgesic activity in mice, compared with the control group.

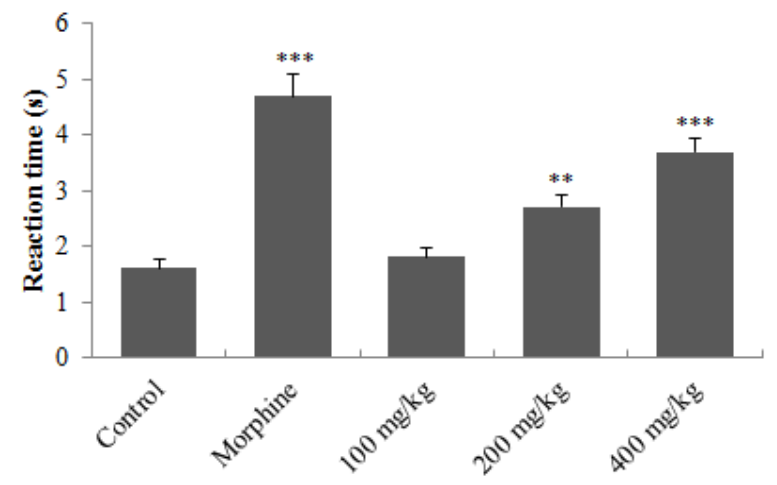

Figure 4: Effect of TA on reaction time in tail-flick test; ${ }^{\star *} p<0.01$, compared with control group; ${ }^{* * *} p<0.001$, compared with control group

\section{Formalin-induced pain}

The results of formalin-induced pain and pretreated with naloxone are shown in Figure 5.
In the phase I, TA significantly reduced the time of licking the paw or leg of mice at the doses of 100,200 , and $400 \mathrm{mg} / \mathrm{kg}(p<0.05, p<0.01$ and $p<0.001$, respectively), compared with the control group dose-dependently. In the phase II, TA also showed significant antinociceptive effect at the doses of 100,200 , and $400 \mathrm{mg} / \mathrm{kg}(p<$ $0.05, p<0.001$ and $p<0.001$, respectively) dose-dependently, compared with the control group.

In addition, naloxone (1 $\mathrm{mg} / \mathrm{kg}$ ) showed no antinociceptive effect on formalin induced pain. However, pretreated with naloxone decreased the anti-nociceptive effect of morphine ( $p<$ 0.001, compared with morphine group). Interestingly, the antinociceptive effect of TA (400 mg/kg) was not decreased by pretreating with naloxone $(p>0.05$, compared with the TA group of $400 \mathrm{mg} / \mathrm{kg}$ ).

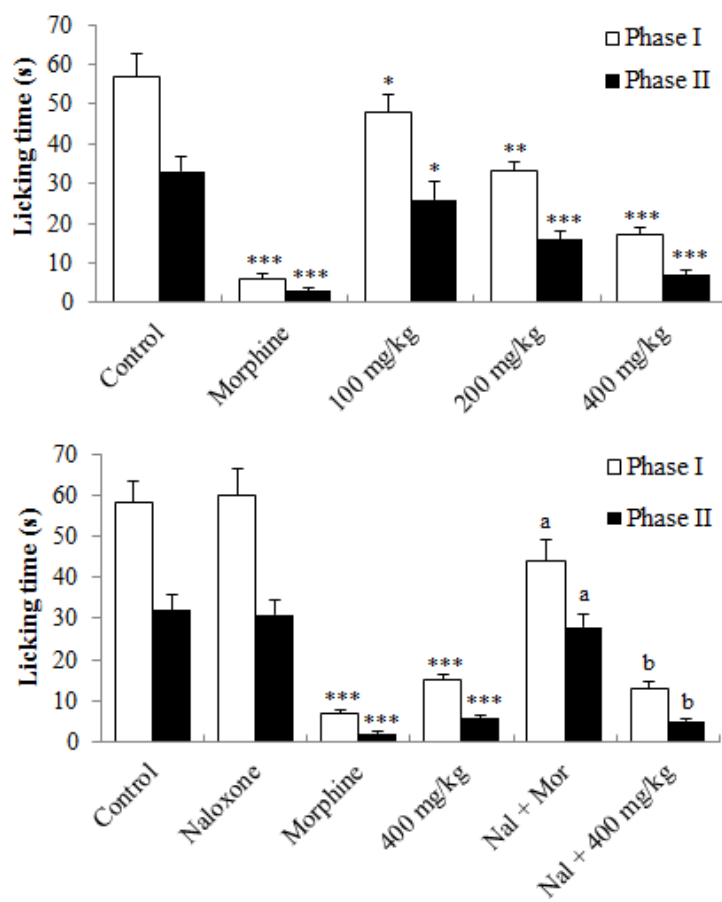

Figure 5: Effect of TA on liking time in formalininduced pain in mice. Mor $=$ Morphine and $\mathrm{Nal}=$ Naloxone; ${ }^{*} p<0.05$, compared with control group; ${ }^{* *} p$ $<0.01$, compared with control group; ${ }^{* \star *} p<0.001$, compared with control group. ${ }^{a} p<0.001$, compared with Morphine group; ${ }^{b} p>0.05$, compared with TA (400 mg/kg) group

\section{Effect of TA on COX-2 in formalin induced pain}

As shown in Figure 6, TA significantly downregulated the expression of COX-2 in dorsal root of mice spinal cord at the doses of 100, 200 and $400 \mathrm{mg} / \mathrm{kg}$, compared with control group. Furthermore, TA showed inhibitory effect on 
expression of COX-2 in dorsal root of formalin induced pain mice $(100,200$ and $400 \mathrm{mg} / \mathrm{kg})$.

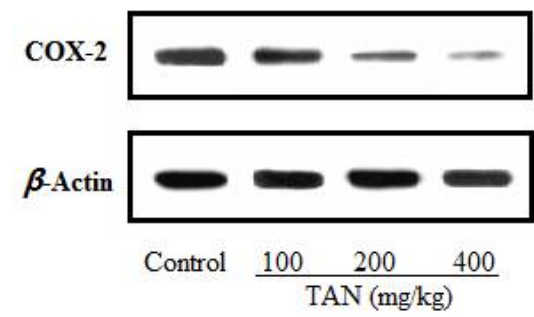

Figure 6: Effect of TA on COX-2 in in formalin induced pain in dorsal root of mice spinal cord

\section{Effect of TA on locomotor activity}

As shown in Figure 7 , diazepam (2 $\mathrm{mg} / \mathrm{kg}$ ) significantly decreased the number of locomotor activity of mice compared with the mice in the control group. However, the number of locomotor activity of mice in TA treated group had no significant difference compared with the control group. Thus, it indicated that TA had no significant effect on spontaneous activity at 100 , 200 and $400 \mathrm{mg} / \mathrm{kg}$ by oral administration in mice $(p>0.05)$.

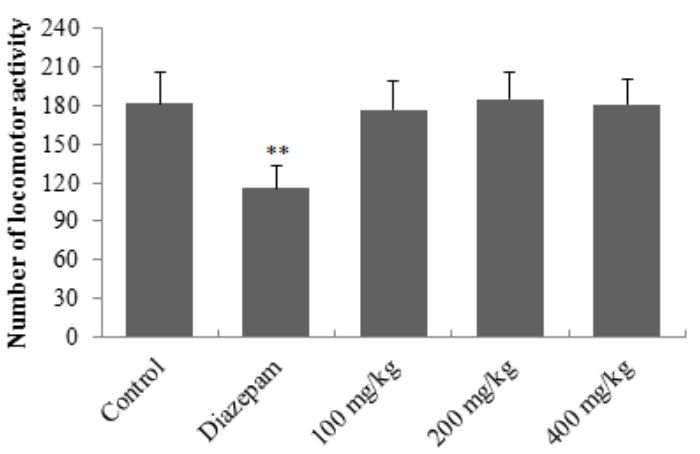

Figure 7: Effect of TA on locomotor activity in mice; ${ }^{\star *} p<0.01$, compared with the control group.

\section{DISCUSSION}

The present study demonstrated that oral administration of TA produces a marked antinociceptive activity when tested in different experimental models of nociception including acetic acid writhing reflex test, hot plate test, capsaicin-induced nociception test, tail-flick test and formalin-induced pain test.

It's reported that the acetic acid-induced writhing response is a sensitive test commonly used for screening anti-nociceptive effect, regardless of the central or peripheral causes [20]. The results indicated that TA exerted significant antinociceptive effects on acetic acid induced writhing reflex in mice with dose-dependent manner. Further studies on hot plate test, capsaicin-induced nociception and tail-flick test also demonstrated that TA possesses significant anti-nociceptive effects on a variety of stimulation induced nociception. In the formalin test, the phase I $(0-5 \mathrm{~min})$ is characterized by neurogenic pain caused by a direct stimulation of nociceptors, while the phase II (15 - $25 \mathrm{~min})$ is characterized by inflammatory pain [21]. In general, centrally acting drugs inhibit phase $I$ and phase II equally, while peripherally acting drugs inhibit mainly the phase II. The results of formalin test indicated that TA had central and peripheral anti-nociceptive properties. As is known to all, naloxone is a one of non-selective opioid receptor antagonists [22]. Pretreatment with naloxone $(2 \mathrm{mg} / \mathrm{kg})$ didn't reverse the antinociceptive activity of TA administered orally. Thus, the results suggested that the opioid route was not involved in the observed anti-nociceptive activity of TA.

COX-2 is an inducible enzyme which is responsible for the production of the proinflammatory prostaglandins (PEG) [23]. TA showed obvious inhibitory effect on the expression of COX-2, indicating that it might be a potent COX-2 inhibitor. Thus, TA had the potential to develop into drugs for treating pain from COX-2 involved-inflammatory diseases.

In the evaluation of the anti-nociceptive effect drugs, it's a major concern whether the treatment of the drugs causes other behavioral alterations, such as sedation or impairment of motor coordination. These behavioral alterations might be misinterpreted as anti-nociceptive effect [24]. In the present study, the locomotor activity of mice was not affected by TA, indicating that its anti-nociceptive effect was highly selective.

\section{CONCLUSION}

The findings of the present study demonstrate that TA possesses significant anti-nociceptive effects. Its effect is not induced by the opioid route, but is closely related to suppression of COX-2 expression. Overall, the results provide some scientific support for the use of TA in the treatment of pain in traditional medicine.

\section{DECLARATIONS}

\section{Conflict of Interest}

No conflict of interest associated with this work.

\section{Contribution of Authors}

The authors declare that this work was done by 
the authors named in this article and all liabilities pertaining to claims relating to the content of this article will be borne by them.

\section{Open Access}

This is an Open Access article that uses a funding model which does not charge readers or their institutions for access and distributed under the terms of the Creative Commons Attribution License (http://creativecommons.org/licenses/by 14.0) and the Budapest Open Access Initiative (http://www.budapestopenaccessinitiative.org/rea d), which permit unrestricted use, distribution, and reproduction in any medium, provided the original work is properly credited.

\section{REFERENCES}

1. Macintyre PE, Huxtable CA, Flint SL, Dobbin MD. Costs and consequences: a review of discharge opioid prescribing for ongoing management of acute pain. Anaesth Intensive Care 2014; 42(5): 558-574.

2. Pinheiro MM, Radulović NS, Miltojević AB, Boylan F, Dias Fernandes P. Antinociceptive esters of $N$ methylanthranilic acid: Mechanism of action in heatmediated pain. Eur J Pharmacol 2014; 727: 106-114.

3. Giorno TB, Silva BV, Pinto Ada C, Fernandes PD. Antinociceptive effect and mechanism of action of isatin, $\mathrm{N}$-methyl isatin and oxopropyl isatin in mice. Life Sci 2016; 151: 189-198.

4. Zhang $H$, Wu L, Liu $Y$, Peng $S$, Wang $W$. The antinociceptive effect and mechanism of action of SY0916. Int Immunopharmacol 2016; 32: 16-23.

5. Makris UE, Abrams RC, Gurland B, Reid MC. Management of persistent pain in the older patient: a clinical review. JAMA 2014; 312(8): 825-836.

6. Wirth JH, Hudgins JC, Paice JA. Use of herbal therapies to relieve pain: a review of efficacy and adverse effects. Pain Manag Nurs 2005; 6(4): 145-167.

7. Wang CC, Lin YR, Liao MH, Jan TR. Oral supplementation with areca-derived polyphenols attenuates food allergic responses in ovalbuminsensitized mice. BMC Complement Altern Med 2013; 13: 154.

8. Editorial Committee of Chinese Pharmacopoeia. Chinese Pharmacopoeia. Beijing: China Medical Science and Technology Press; 2010. p. 342-343.

9. Liu YJ, Peng $W$, Hu MB, Xu M, Wu CJ. The pharmacology, toxicology and potential applications of arecoline: a review. Pharm Biol 2016:1-8. [Epub ahead of print]

10. Peng W, Liu YJ, Wu N, Sun T, He XY, Gao YX, Wu CJ. Areca catechu $L$. (Arecaceae): a review of its traditional uses, botany, phytochemistry, pharmacology and toxicology. J Ethnopharmacol 2015; 164: 340-356.
11. Luo SS, Zhang HD, LI GS, Zhu L. Study on ultrasonic extraction process of arecoline from betel nut. Food Sci Tech (China) 2010; 35(8): 240-243.

12. Yang $Q X$, He MJ, Lu LL, Hou M. Determination of Total Alkaloids from Different Areca nut( Areca catechu Linn)Germplasm by Acid Dye Colorimetry Method. Mod Chin Med (China). 2014, 16(3): 199-201.

13. "Principles of Laboratory Animal Care" (NIH publication no. 85-23, revised 1985). Available from: http://grants 1.nih.gov/grants/olaw/references/phspol.htm

14. Wang $Y$, Chen $Y, X u H$, Luo H, Jiang R. Analgesic effects of glycoproteins from Panax ginseng root in mice. $J$ Ethnopharmacol 2013; 148(3): 946-950.

15. Suseem SR, Mary Saral A, Neelakanda Reddy P, Marslin $G$. Evaluation of the analgesic activity of ethyl acetate, methanol and aqueous extracts of Pleurotus eous mushroom. Asian Pac J Trop Med 2011; 4(2): 117-120.

16. Pinheiro MM, Radulović NS, Miltojević AB, Boylan F, Dias Fernandes P. Antinociceptive esters of $\mathrm{N}$ methylanthranilic acid: Mechanism of action in heatmediated pain. Eur J Pharmacol 2014 Mar 15; 727: 106114.

17. Zhang $H$, Wu L, Liu Y, Peng S, Wang W. The antinociceptive effect and mechanism of action of SY0916. Int Immunopharmacol 2016; 32: 16-23.

18. Wandji BA, Tatsinkou Bomba FD, Awouafack MD, Nkeng-Efouet $P A$, Kamanyi A1, Nguelefack TB. Antinociceptive effects of the aqueous and methanol extracts of the leaves of Pittosporum mannii Hook. F. (Pittosporaceae) in mice. J Ethnopharmacol 2016; 187: 224-231.

19. Wang QS, Yang L, Cui WY, Chen L, Jiang YH. Antiinflammatory and anti-nociceptive activities of methanol extract from aerial part of Phlomis younghusbandii Mukerjee. PLoS One 2014; 9(3): e89149.

20. Moniruzzaman M, Hossain MS, Bhattacharjee PS. Evaluation of antinociceptive activity of methanolic extract of leaves of Stephania japonica Linn. J Ethnopharmacol 2016; 186: 205-208.

21. Hunskaar $S$, Hole $K$. The formalin test in mice: dissociation between inflammatory and noninflammatory pain. Pain. 1987; 30(1):103-114.

22. Campos $D C$, Costa $A S$, Lima $A D$, Silva $F D$, Lobo $M D$, Monteiro-Moreira AC, Moreira RA, Leal LK, Miron D, Vasconcelos $I M$, et al. First isolation and antinociceptive activity of a lipid transfer protein from noni (Morinda citrifolia) seeds. Int J Biol Macromol 2016; 86: 71-79.

23. Park MK, Lee HJ, Choi JK, Kim HJ, Kang JH, Lee EJ, Kim YR, Kang JH, Yoo JK, Cho HY, et al. Novel antinociceptive effects of cardamonin via blocking expression of cyclooxygenase-2 and transglutaminase2. Pharmacol Biochem Behav. 2014; 118: 10-15.

24. Zheng Y, Yin X, Huo F, Xiong H, Mei Z. Analgesic effects and possible mechanisms of iridoid glycosides from Lamiophlomis rotata (Benth.) Kudo in rats with spared nerve injury. J Ethnopharmacol 2015; 173: 204-211. 